\title{
Age Limits of Criminal Responsibility for Property Offences: A New Empirical Research on Legal Consciousness in Hungary
}

\author{
MiKLÓs HolláN* \\ TÍMEA VENCZEL ${ }^{* *}$
}

\begin{abstract}
This research focuses on the question whether novelties of criminal law are mirrored in legal consciousness. A questionnaire-based survey was conducted on a representative national sample of the adult Hungarian population and in this paper, the responses related to the age-limit of criminal responsibility for property offences are analysed. The hypothesis that the average person has a fragmented knowledge, even about this sector of criminal law, has been verified. It was not substantiated that this knowledge of law is substantially affected by socio-economic factors, including media consumption and encountering criminality. The cognitive answers were, however, strongly influenced by the attitudes of the respondents. ${ }^{1}$
\end{abstract}

Keywords: novelties, criminal law, legal consciousness, survey, age limits of criminal responsibility

\section{PREVIOUS RESEARCH PROJECTS ON LEGAL CONSCIOUSNESS: A BRIEF OVERVIEW}

Engel distinguishes two alternative meanings of legal consciousness: aptitude, competence or awareness of the law; and perceptions or images of law. ${ }^{2}$ According to Hertogh, most studies on legal alienation focus on two basic questions: 'Are people aware of the law?,' 'Do people identify with the law?'3

Two traditions of legal consciousness studies have been distinguished: (1) the American conception, derived from Roscoe Pound, whose focus is on written law, even when researching 'law in action,' and (2) the European conception, which is represented by Eugen Ehrlich. The 'primary focus of this conception is: What do people experience as 'law'?'4

Most empirical research until the 1970s was based on the conviction that public knowledge of and opinion about (primarily written) law were measurable so the most commonly used method was the large-sample survey. This is the KOL (knowledge and opinion about law) literature.

In recent decades, researchers have assumed that legal systems are not simply 'social facts acting upon society' (law and society) but instead, law is the label given to a certain

* Senior Research Fellow, Centre for Social Sciences Institute for Legal Studies Hungarian Academy of Sciences Centre of Excellence, hollan.miklos@tk.mta.hu.

** Junior Research Fellow, Centre for Social Sciences Institute for Legal Studies Hungarian Academy of Sciences Centre of Excellence, venczel.timea@tk.mta.hu.

1 Research was carried out in the framework of the project 'Novelties of criminal law and legal consciousness' supported by the NKFIH (K 125378) 2017-2020.

2 Engel (1998) 119.

3 Hertogh (2010) 15.

4 Hertogh (2004) 475. 
aspect of society (law in society). They focused primarily on what ideas people have about law and legal institutions. The methodology of the latter research, in contrast to the KOL research, is that of descriptive ethnography. ${ }^{5}$

Research on legal consciousness is not only suitable for comparing different societies and groups but also for comparing different perceptions and understandings on different fields of law. ${ }^{6}$

It was argued that 'different substantive areas of law are associated with different perceptions, understandings and behaviours and must, therefore, be distinguished in research on legal consciousness.' 7

Legal awareness surveys were conducted in Hungary, in the 1960s and 1970s, under the leadership of Kálmán Kulcsár and András Sajó, ${ }^{8}$ which, similarly to the current project also measured awareness of criminal law with quantitative tools, usually on a national representative sample.

Fekete and H. Szilágyi summarize the KOL research in socialist Hungary as follows: 'The KOL studies of the socialist era created a tradition that can be continued today. This tradition offers an excellent starting point for comparative studies in terms of the empirical data, methodology and theoretical conceptions. ${ }^{9}$

Fekete and Gajduschek partially repeated one of Kulcsár's surveys to assess the 'changes in knowledge about law in Hungary in the past half century.' ${ }^{10}$ Surveys on legal knowledge became less common after the change of regime but surveys related to criminal law occurred sporadically. ${ }^{11}$ However, questions about knowledge and opinions about the age limit of criminal responsibility were not included.

\section{AGE LIMITS IN HUNGARIAN CRIMINAL LAW}

Traditionally, Hungarian criminal law (Criminal Code of 1878, henceforth 'HCC 1878,' and the General Part of the Criminal Code of 1950, henceforth 'HCC 1950') only made the prosecution of persons over the age of 12 possible. ${ }^{12}$ In addition, anyone, who at the time the crime or offense was committed, was over the age of 12 but was not 16 , could only be punished, if they had 'the necessary discernment to establish the guiltiness of their act." ${ }^{13}$ HCC 1878 also stated that convicted offenders of this age may not be punished but could only be placed in a correctional institution. ${ }^{14}$

The Criminal Code of 1961 ('HCC 1961') raised the age-limit of criminal responsibility for all types of offenses to $14 .^{15}$ Perpetrators under the age of 14 were only subject to correctional measures regulated by administrative law. Like its predecessor, the Criminal Code of 1978 (HCC 1978) did not make persons under the age of 14 punishable. ${ }^{16}$ Since

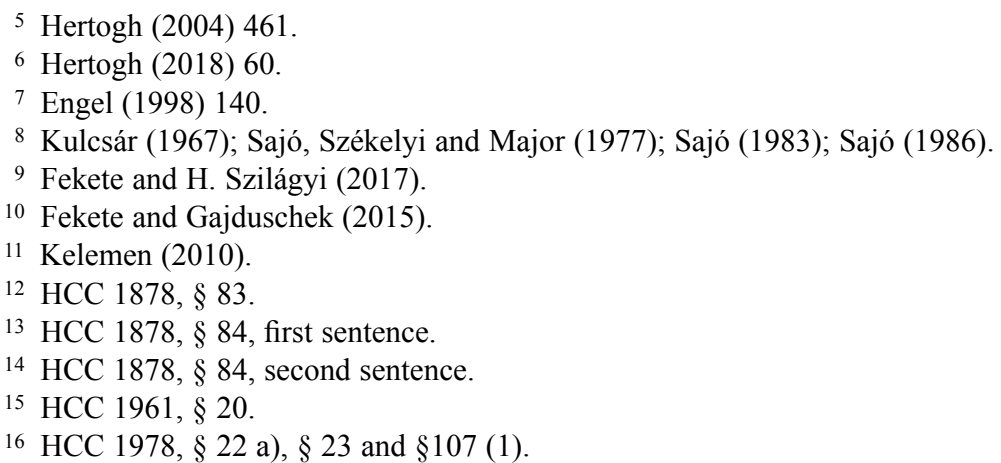


1989, the legal literature has argued both against and in favour ${ }^{17}$ of lowering the age of criminal responsibility. ${ }^{18}$

The proposal of the Hungarian Criminal Code of 2012 ('HCC 2012') lowered the agelimit of criminal responsibility when the perpetrator committed homicide or assault with life-threatening of fatal consequences. ${ }^{19}$ However, a perpetrator of these offenses under the age of 14 could only be prosecuted if they 'had the insight necessary to recognize the consequences of the offense. ${ }^{20}$ Punishments as imprisonment or fine were not applicable against those persons, only correctional measures. ${ }^{21}$

It was argued that, "nowadays [...] the biological development of children has accelerated' and 'as a result of the information technology, minors reach the various influences of society they were previously protected from before the age of fourteen years.' It was also pointed out that 'violent behaviour is increasingly prevalent in children between the ages of twelve and fourteen.' 22

The final version of HCC 2012 was the result of an amendment that extended the scope of the lowered age-limit to offences of robbery and aggravated cases of despoliation. The explanatory memorandum of this proposal stated that these offences 'are analogous to the offences enumerated in the submitted proposal in that they can also be carried out with violence. $^{23}$

This modification was criticised in legal scholarship. Mihály Tóth states 'it is highly doubtful whether the modification was really warranted or whether it was a measure chosen only to serve the demands of the vox populi.' When 'it was required by the severity of the case, the institutionalization of these persons was provided by administrative law (under the Child Protection Act). ${ }^{24}$

\section{METHODS, HYPOTHESES, AND RELATED PARTS OF THE QUESTIONNAIRE}

The conceptual framework and primary tool of KOL research, quantitative data collection, was used in this research. This is justified by the focus of the research, i.e. the knowledge of regulatory novelties, which also links this research methodology to the tradition of focusing on state law. Thus, this research was not a novelty in terms of methodology but in the selection of the examined legal material and in the depth of its examination.

The questions were related to 12 criminal law topics that are more often appearing in everyday life and in the media. The primary selection criterion, in line with the objective of the research, was that the criminal law regulations on the given topic have changed in the last decade.

17 Vaskuti (2009).

18 See in this regard Király (2005).

19 HCC 2012 Proposal, § 16.

20 Balázs (2018).

${ }^{21}$ HCC 2012, § 106 (2), second sentence.

22 HCC 2012 Proposal, official reasoning attached to $\S 16$.

23 Amendment proposal, No. T/6958/169 (30 May 2012).

24 Tóth (2013) 531. 
For each topic (in proportion to the complexity of its regulation) there were two to four questions. One question always concerned a regulatory element whose legal perception had changed. However, a question was also asked about one or more 'control cases' that measured knowledge of an element whose regulation is unchanged.

Respondents had to decide whether the act described is punishable and in addition, they could answer whether the act would have been punished if they were legislators.

The survey fieldwork was conducted by the Median Institute for Opinion and Market Research between October 12 and 17, 2018. The data were collected at the respondents' homes using a structured questionnaire as part of an omnibus survey. The self-administered interview was conducted, with the supervision and assistance of the interviewer, on a sample of 1,200 people representing the adult population of the country. ${ }^{25}$

The research hypotheses were the following:

- an everyday person has a fragmented knowledge about the legal system but the level of legal awareness is higher if it relates to crimes mala in se (e.g. theft and robbery);

- legal consciousness is strongly influenced by ordinary socio-economic factors and also by media consumption and crime-related experiences;

- older norms are more frequently known by an everyday person. ('Legal consciousness is more difficult to change than regulation.')

To explore legal consciousness with regard to age limits of criminal responsibility, respondents were asked to assess four situations:

(1) A 15-year-old knocks down their classmate and takes their cell phone, worth 55,000 HUF.

(2) A 15-year-old takes their classmate's cell phone worth 55,000 HUF.

(3) A 13-year-old knocks down their classmate and takes their cell phone worth 55,000 HUF.

(4) A 13-year-old takes their classmate's cell phone worth 55,000 HUF.

Perpetrators in cases (1)-(3) are criminally liable under the new regulation but in case (4) the perpetrator is not punishable. The third question concerns regulatory novelty because it was not punishable under the former HCC. According to the former regulation, only persons who reached the age of 14 were punishable for criminal offences, regardless of their severity.

\section{THE KNOWLEDGE OF LAW}

\subsection{A relatively high level of legal awareness}

Most respondents (73\%) were aware that persons who reached the age of 15 are punishable for robbery according to the HCC and it is significantly higher than the average legal awareness of all the situations in the survey (56\%). Slightly fewer (63\%) were aware that theft committed by persons of the same age is also punishable. Only slightly more than half $(55 \%)$ of the respondents were aware that a 13-year-old robber could be punished. Fewer $(49 \%)$ were aware that theft committed by persons of the same age is not punishable.

25 The method of sampling was a multistage stratified random process. Smaller sample distortions were corrected by four-dimensional weighting based on gender, age, education, and settlement type, based on census data. For this analysis, the weighted data file was used. 
Table 1. A 15-year-old knocks down his/her classmate during the break and takes away his/her cell phone worth 55,000 HUF. Is it punishable?

\begin{tabular}{|l|c|}
\hline & Awareness \\
\hline Punishable & $\mathbf{7 3}$ \\
\hline Not punishable & 26 \\
\hline Don't know & 1 \\
\hline
\end{tabular}

${ }^{*}$ Without those $(\mathrm{N}=29)$ who did not answer any questions

Table 2. 15-year-old takes away his/her classmate's cell phone worth $\mathbf{5 5 , 0 0 0}$ HUF during the break. Is it punishable?

\begin{tabular}{|l|c|}
\hline \multicolumn{1}{c}{} & Awareness \\
\hline Punishable & $\mathbf{6 3}$ \\
\hline Not punishable & 35 \\
\hline Don't know & 2 \\
\hline
\end{tabular}

* Without those $(\mathrm{N}=29)$ who did not answer any questions

Table 3. A 13-year-old knocks down his/her classmate during the break and takes away his/her cell phone worth 55,000 HUF. Is it punishable?

\begin{tabular}{|l|c|}
\hline \multicolumn{1}{|c|}{ (percentage) } \\
\hline Punishable & $\mathbf{5 5}$ \\
\hline Not punishable & 43 \\
\hline Don't know & 2 \\
\hline
\end{tabular}

${ }^{*}$ Without those $(\mathrm{N}=29)$ who did not answer any questions

Table 4. A 13-year-old takes away his/her classmate's cell phone worth 55,000 HUF during the break. Is it punishable?

\begin{tabular}{|l|c|}
\hline \multicolumn{1}{c}{} & (percentage) \\
\hline Punishable & Awareness \\
\hline Not punishable & 49 \\
\hline Don't know & $\mathbf{4 9}$ \\
\hline
\end{tabular}

${ }^{*}$ Without those $(\mathrm{N}=29)$ who did not answer any questions 


\subsection{The schematic nature of legal knowledge}

The majority of respondents $(67 \%)$ do not consider the type of the act or the age of the perpetrator as a factor influencing criminal responsibility. Around $44 \%$ thought that the offense was punishable regardless of whether the offender was 15 or 13 years old or whether they robbed or stole. According to the knowledge of these respondents, each situation, therefore, constitutes a criminal offense under the legislation in force. More than two-tenth $(23 \%)$, on the contrary, believe that none of the cases qualifies as a crime for persons of this age.

However, one third of respondents said that there is a difference between the regulations of the situations. Almost a quarter of all respondents $(23 \%$ and $24 \%)$ are aware of differentiation by the age of the offender and about one tenth $(9 \%$ and $12 \%)$ are aware of regulatory difference by the type of the act.

With regard to acts committed by 15 -year-old persons, the majority know that theft and robbery are punishable. With regard to 13-year-old perpetrators, the proportion of those who say they are going to be punished in both cases and those who thought none of the cases is punishable is almost the same. Compared to this, the difference between theft and robbery is much smaller: in the case of robbery, slightly more people know that offenders may be punished in both cases.

Table 5. Perception of similarity on the basis of awareness in the four situations

(percentage of all respondents)

\begin{tabular}{|l|c|c|c|c|}
\hline & $\begin{array}{c}\text { Both situations } \\
\text { are known } \\
\text { to be punishable }\end{array}$ & $\begin{array}{c}\text { None of the situations } \\
\text { are known } \\
\text { to be punishable }\end{array}$ & It varies & Don't know \\
\hline 15 year olds & 62 & 25 & 12 & 1 \\
\hline 13 year olds & 48 & 42 & 9 & 1 \\
\hline Robbery & 52 & 23 & 24 & 1 \\
\hline Theft & 45 & 31 & 23 & 1 \\
\hline
\end{tabular}

* Without those $(\mathrm{N}=29)$ who did not answer any questions

Taking into account only the knowledge of those who did not consider the regulation of all situations to be the same there is a clear 'diagonal pattern.' 15-year-olds are punishable for both theft and robbery whilst the opposite is true for 13-year-olds as they are not punishable for either offense. Likewise, both 13 and 15-year-olds are held criminally responsible for robbery while the same ratio of respondents think the opposite is true for theft: no one these agegroups is punishable.

More people think that the age of the perpetrator matters than the difference between robbery and theft. 
Table 6. Perception of similarity on the basis of awareness in the four situations

(in the percentage of those who have different awareness on the criminalization of the four situations, $\mathrm{N}=381$ )

\begin{tabular}{|l|c|c|c|c|}
\hline & $\begin{array}{c}\text { Both of the situations } \\
\text { are known } \\
\text { to be punishable }\end{array}$ & $\begin{array}{c}\text { None of the situations } \\
\text { are known } \\
\text { to be punishable }\end{array}$ & It varies & Don't know \\
\hline 15 year olds & $\mathbf{5 4}$ & 9 & 37 & 0 \\
\hline 13 year olds & 10 & $\mathbf{5 9}$ & 29 & 2 \\
\hline Robbery & $\mathbf{2 3}$ & 3 & 74 & 0 \\
\hline Theft & 3 & $\mathbf{2 8}$ & 67 & 2 \\
\hline
\end{tabular}

\subsection{The fragmented nature of legal awareness}

Only $3 \%$ of all respondents are fully aware of the age-limits of criminal responsibility for offences against property. Two-thirds (62\%) of the respondents answered three questions correctly. Most (44\%) are unaware that a 13-year-old thief is not punished.

A quarter of respondents $(25 \%)$ can answer only one question correctly: the vast majority (22\%) of it knew of the impunity of a 13-year-old thief. However, those who responded in this way had the same answer not punishable for all other situations as well. It means this was more of a schematic response, rather than a real manifestation of legal knowledge.

\section{Table 7. Number of correct answers}

\begin{tabular}{|l|c|}
\multicolumn{2}{c}{} \\
\hline & (percentage) \\
\hline None & 1 \\
\hline One & 25 \\
\hline Two & 9 \\
\hline Three & 62 \\
\hline All four & 3 \\
\hline Total & $\mathbf{1 0 0}$ \\
\hline
\end{tabular}

Table 8. Combinations of correct answers

\begin{tabular}{|l|c|}
\hline & Awareness \\
\hline The only thing they don't know that a 13-year-old thief is punished & 44 \\
\hline The only thing they know that a 13-year-old thief is punished & 22 \\
\hline The only thing they don't know that a 13-year-old robber is punished & 14 \\
\hline The only thing they don't know that a 15-year-old theft is punished & 4 \\
\hline $\begin{array}{l}\text { The only thing they know that a 15-year-old robber is punished and the 13-year-old } \\
\text { thief is not punished }\end{array}$ & 3 \\
\hline Correct answers for all the four situation & 3 \\
\hline Other & $\mathbf{1 0 0}$ \\
\hline Total & 8 \\
\hline
\end{tabular}




\subsection{Knowledge of novelties}

One of the basic questions of this research was whether the time elapsed since the creation of a regulation has any impact on the knowledge of law. This hypothesis could not be validated with regard to the age-limit of criminal responsibility for offences against property. Respondents were not the least aware of the issue of the criminalization of a 13-year-old robber. However, based on the data, the hypothesis cannot be refuted. Indeed, when comparing only those situations in which 'punishable' was the correct answer according to the HCC of 2012, the novelty is the least known regulation.

\subsection{Knowledge and socio-demographic groups}

A bivariate logistic regression was run to predict legal awareness from socio-demographic variables and from opinion about the given situation. The dependent variable of the regression model was the bivariate, crime / non-crime response for each situation. Among the independent variables, in addition to the socio-demographic variables, we included the opinion on the given situation. ${ }^{26}$

The model explained 23-25\% (Nagelkerke $\mathrm{R}^{2}$ ) of the variance in the answer. In all cases, the most influential variables were the opinions on the same scenario.

It can be seen from the table that frequency of visiting church also showed a significant $(p=0.05)$ correlation with the responses to all situations. However, the fact that those who rarely go to church are more likely to say that a given situation is a crime even when it is not the correct answer also suggests that the answers are not, in fact, so much about knowledge as it is about opinion. Overall, the influence of opinion is much stronger than that of church attendance.

Table 9. Legal awareness of the four situations. Bivariate logistic regression model

\begin{tabular}{|l|c|c|c|c|c|c|c|c|}
\hline & $\begin{array}{c}\text { A } \\
\text { 15-year- } \\
\text { old } \\
\text { knocks } \\
\text { down } \\
\text { and takes } \\
\text { away }\end{array}$ & $\begin{array}{c}\text { Nagelkerke } \\
\mathrm{R}^{2}=0,240\end{array}$ & $\begin{array}{c}\text { A } \\
\text { 15-year- } \\
\text { old takes } \\
\text { away }\end{array}$ & $\begin{array}{c}\text { Nagelkerke } \\
\mathrm{R}^{2}=0,240\end{array}$ & $\begin{array}{c}\text { A } \\
\text { 13-year- } \\
\text { old } \\
\text { knocks } \\
\text { down } \\
\text { and takes } \\
\text { away }\end{array}$ & $\begin{array}{c}\text { Nagelkerke } \\
\mathrm{R}^{2}=0,225\end{array}$ & $\begin{array}{c}\text { A } \\
\text { 13-year- } \\
\text { old takes } \\
\text { away }\end{array}$ & $\begin{array}{c}\text { Nagelkerke } \\
\mathrm{R}^{2}=0,246\end{array}$ \\
\hline Opinion &, 000 & 19,190 &, 000 & 12,378 &, 000 & 15,140 &, 000 & 12,479 \\
\hline Church &, 026 &, 814 &, 001 &, 746 &, 024 &, 825 &, 002 &, 762 \\
\hline Work &, 019 & 1,168 &, 007 & 1,183 &, 058 & 1,126 &, 029 & 1,152 \\
\hline
\end{tabular}

26 The following independent variables were included in the analysis: Gender (1: male; 2: female); Financial situation (1: better; 2: about the same; 3: worse than other Hungarian families); Size of settlement (1: less than 1000 inhabitants; 8: more than 100,000 inhabitants, 9: Budapest) Do you go to church? (1: several times a week; 6 : does not go to church or religious gatherings at all); Work (1: full-time; 8: inactive earner); Family size; Number of people over 60; Number of children under 18; Per capita income; Age; Education; Are you watching TV news? (0: no; 1: watch RTL or TV2 News at least once a week); Have you been involved in a crime? (0: no, 1: yes); Do you read a daily newspaper? (1: no; 2: yes); What do you think about the given situation? (1: should be punished; should not be punished). 


\begin{tabular}{|c|c|c|c|c|c|c|c|c|}
\hline & \begin{tabular}{|c|} 
A \\
15-year- \\
old \\
knocks \\
down \\
and takes \\
away \\
\end{tabular} & $\begin{array}{c}\text { Nagelkerke } \\
\mathrm{R}^{2}=0,240\end{array}$ & $\begin{array}{c}\text { A } \\
\text { 15-year- } \\
\text { old takes } \\
\text { away }\end{array}$ & $\begin{array}{c}\text { Nagelkerke } \\
\mathrm{R}^{2}=0,240\end{array}$ & $\begin{array}{c}\text { A } \\
\text { 13-year- } \\
\text { old } \\
\text { knocks } \\
\text { down } \\
\text { and takes } \\
\text { away }\end{array}$ & $\begin{array}{c}\text { Nagelkerke } \\
\mathrm{R}^{2}=0,225\end{array}$ & $\begin{array}{c}\text { A } \\
\text { 13-year- } \\
\text { old takes } \\
\text { away }\end{array}$ & $\begin{array}{c}\text { Nagelkerke } \\
R^{2}=0,246\end{array}$ \\
\hline & $\mathrm{p}$ & $\exp (B)$ & $\mathrm{p}$ & $\exp (B)$ & $\mathrm{p}$ & $\exp (B)$ & $\mathrm{p}$ & $\exp (B)$ \\
\hline Family size & ,921 & 1,012 & 892 & 1,016 & ,001 & 1,476 & ,002 & 1,456 \\
\hline Education & ,265 & 1,195 & ,588 & 1,086 & ,025 & 1,374 &, 065 & 1,303 \\
\hline $\begin{array}{l}\text { Financial } \\
\text { situation }\end{array}$ & ,066 & 1,489 & 054 & 1,450 & 057 & 1,421 &, 043 & 1,451 \\
\hline $\begin{array}{l}\text { Number } \\
\text { of children } \\
\text { under } 18\end{array}$ & ,804 & 1,046 & ,299 & 1,200 & ,004 & ,600 & ,078 & ,737 \\
\hline $\begin{array}{l}\text { Reading } \\
\text { newspaper }\end{array}$ & ,016 & 1,759 & ,788 & 1,063 & ,816 & ,951 & ,221 & ,766 \\
\hline Gender & 088 & 683 & ,743 & ,934 & ,346 & 831 & ,463 & 865 \\
\hline $\begin{array}{l}\text { Settlement } \\
\text { size }\end{array}$ & ,367 & 1,039 & 205 & 1,052 & ,769 & 1,011 & ,400 & 1,032 \\
\hline $\begin{array}{l}\text { Number } \\
\text { of people } \\
\text { over } 60\end{array}$ & ,756 & ,909 & ,974 & ,991 & ,605 & ,869 & ,603 & ,868 \\
\hline $\begin{array}{l}\text { Income } \\
\text { per capita }\end{array}$ & ,394 & 1,000 & ,381 & 1,000 & ,550 & 1,000 & ,838 & 1,000 \\
\hline Age & 084 & ,986 & ,333 & ,993 & ,831 & 1,002 &, 727 & 1,003 \\
\hline $\begin{array}{l}\text { Watching } \\
\text { the news }\end{array}$ & ,955 & 1,015 & ,474 & ,839 & , 106 & ,690 & ,408 & ,822 \\
\hline $\begin{array}{l}\text { Involved } \\
\text { in crime }\end{array}$ & , 152 & ,662 & , 400 & 805 &, 323 & 1,267 & ,113 & 1,481 \\
\hline
\end{tabular}

$\mathrm{p}=0,05$; significant variables with grey background

However, it may be concluded that in case of the questions on the age-limit of criminal responsibility, these results do not necessarily reflect an exact knowledge of statutory instruments. Even former researchers touched upon the question of whether the measured data were based on positive legal knowledge or simply the standard of moral norms or the influence of social practice. ${ }^{27}$

\section{OPINIONS}

\subsection{Strong willingness to punish}

More than nine-tenths (92\%) of respondents would punish a 15-year-old robber. Almost the same ratio $(87 \%)$ of respondents gave the same answer about their opinion when the criminal responsibility of a 15 -year-old thief was concerned. Nearly nine-tenths $(89 \%)$ was 
the ratio of those who would punish a 13-year-old robber, and slightly more than eighttenths of respondents would do the same with a 13-year-old thief.

Table 10. A 15-year-old knocks down his/her classmate during the break and takes away his/her cell phone worth 55,000 HUF. Should he/she or should not be punishable?

(percentage)

\begin{tabular}{|l|c|}
\hline & Opinion \\
\hline Should be punishable & 92 \\
\hline Should not be punishable & 6 \\
\hline Don't know & 2 \\
\hline
\end{tabular}

* Without those $(\mathrm{N}=29)$ who did not answer any questions

Table 11. A 15-year-old takes away his/her classmate's cell phone worth 55,000 HUF during the break. Should he/she or should not be punishable?

(percentage)

\begin{tabular}{|l|c|}
\hline & Opinion \\
\hline Should be punishable & 87 \\
\hline Should not be punishable & 11 \\
\hline Don't know & 2 \\
\hline
\end{tabular}

* Without those $(\mathrm{N}=29)$ who did not answer any questions

Table 12. A 13-year-old knocks down his/her classmate during the break and takes away his/hercell phone worth 55,000 HUF. Should he/she or should not be punishable?

\begin{tabular}{|l|c|}
\hline \multicolumn{1}{c}{ (percentage) } \\
\hline Should be punishable & Opinion \\
\hline Should not be punishable & 89 \\
\hline Don't know & 2 \\
\hline
\end{tabular}

${ }^{*}$ Without those $(\mathrm{N}=29)$ who did not answer any questions

Table 13. A 13-year-old takes away his/her classmate's cell phone worth $\mathbf{5 5 , 0 0 0}$ HUF during the break. Should he/she or should not be punishable?

(percentage)

\begin{tabular}{|l|c|}
\hline & Opinion \\
\hline Should be punishable & 83 \\
\hline Should not be punishable & 16 \\
\hline Don't know & 1 \\
\hline
\end{tabular}

${ }^{*}$ Without those $(\mathrm{N}=29)$ who did not answer any questions 
An overwhelming majority (79\%) would punish all four of these acts. Very few (5\%) would punish none of them. All together $88 \%$ of respondents formulated a punitive opinion, which is significantly higher than the average of the survey (75\%). Therefore, the willingness of Hungarian society to punish is high with regard to age-limits of criminal responsibility for crimes against property.

Table 14. How many of the four situations should be punishable?

(percentage)

\begin{tabular}{|l|c|}
\hline & Opinion \\
\hline None & 5 \\
\hline One & 1 \\
\hline Two & 9 \\
\hline Three & 6 \\
\hline All four & 79 \\
\hline Total & $\mathbf{1 0 0}$ \\
\hline
\end{tabular}

\subsection{Patterns of opinions}

Overall, $16 \%$ of respondents would make a difference in regulation based on the type of act or age of the perpetrator. More than eight-tenths of respondents would punish perpetrators of both ages and both types of acts. Eight percent would not punish a 13-year-old perpetrator for any crime against property, while only 5\% would leave a 15 -year-old perpetrator unpunished. Similarly, theft would be unpunishable at both ages, according to the opinion of $9 \%$ of respondents, while $4 \%$ in cases of robbery.

Table 15. Perception of similarity on the basis of opinions in the four situations

(percentage of all respondents)

\begin{tabular}{|l|c|c|c|c|}
\hline & $\begin{array}{c}\text { Both of the situations } \\
\text { are judged } \\
\text { to be punishable }\end{array}$ & $\begin{array}{c}\text { None of the situations } \\
\text { are judged } \\
\text { to be punishable }\end{array}$ & It varies & Don't know \\
\hline 15 -year-olds & 85 & 5 & 8 & 2 \\
\hline 13 -year-olds & 82 & 8 & 9 & 1 \\
\hline Theft & 81 & 9 & 9 & 1 \\
\hline Robbery & 86 & 4 & 8 & 2 \\
\hline
\end{tabular}

* Without those $(\mathrm{N}=29)$ who did not answer any questions

Most of the opinions are in the same vein: respondents mostly would punish all four situations. Those who differentiate $(16 \%)$ are most likely to punish robbery regardless of age $(47 \%)$ and 15 -year-olds regardless of the act $(41 \%)$. However, nearly three-tenths (28\%) would not punish 13-year-olds for any crime against property. On the other hand, a few more (33\%) would not punish theft by either 13 or 15 -year-olds. All in all, the otherwise strict public opinion is somewhat more lenient towards 13 -year-olds than 15-year-olds, and also more lenient against theft than robbery. Public opinion on these questions, thus, points in the same direction as the actual regulation. 
Table 16. Perception of similarity on the basis of opinions in the four situations

(in the percentage of those who have different opinions on the criminalization of the four situations, $\mathrm{N}=193$ )

\begin{tabular}{|c|c|c|c|c|}
\hline & \begin{tabular}{|c|} 
both of the \\
situations \\
are judged \\
to be punishable
\end{tabular} & \begin{tabular}{|c|} 
none of the \\
situations \\
are judged \\
to be punishable
\end{tabular} & vary & $\begin{array}{l}\text { don't } \\
\text { know }\end{array}$ \\
\hline 15-year-olds & 41 & 7 & $\begin{array}{c}49 \\
(37 \% \text { would punish robber) }\end{array}$ & 3 \\
\hline 13-year-olds & 19 & 28 & $\begin{array}{c}53 \\
(43 \% \text { would punish robber) }\end{array}$ & 0 \\
\hline theft & 13 & 33 & $\begin{array}{c}54 \\
\text { (39\% would punish the } 15 \text { year olds } \\
\text { and wouldn't punish } \\
\text { the } 13 \text { year olds) }\end{array}$ & 0 \\
\hline robbery & 47 & 4 & $\begin{array}{c}47 \\
\text { (29\% would punish the } 15 \text { year olds) }\end{array}$ & 2 \\
\hline
\end{tabular}

\subsection{Conformity of opinions with the current and former regulations}

Only 3\% of respondents would regulate crimes against property fully in line with the actual Hungarian criminal code. This is the ratio of those who would not punish only those (the thirteen-year-old thief) who are not punishable by law. The support for the new set of rules is $71 \%$, while that for the old one is $52 \%$. All this shows the punitivity of the population: they support the criminalization by the new regulation.

Table 17. Different combinations of opinions on criminalization

\begin{tabular}{|l|c|}
\hline & Opinion \\
\hline Would only punish robbery (regardless of age) & 4 \\
\hline Would only punish 15 year olds (regardless of act) & 3 \\
\hline Would punish everyone except the 13 year old theft & $\mathbf{3}$ \\
\hline Would punish all the cases & 79 \\
\hline Would punish none of the cases & 5 \\
\hline Other & 6 \\
\hline Total & $\mathbf{1 0 0}$ \\
\hline
\end{tabular}

\subsection{Opinions vs. the supposed regulation}

In each of the four situations, there is a majority whose knowledge of law is consistent with their opinion, and the proportion of those who believe the law punishes something that they would not punish is almost negligible (1 or $2 \%$ ). Differences in opinion and knowledge tend to lead to criminalization (22-36\%). There is a higher percentage of those who want to criminalize 13-year-olds because they think that they are not being punished at the moment and this is condemned by them. 
Table 18. Opinion vs. supposed regulation

(only among those who reported their awareness and opinion of the regulation, percentage)

\begin{tabular}{|l|c|c|c|c|}
\hline & $\begin{array}{c}\text { Agree with } \\
\text { the } \\
\text { supposed } \\
\text { regulation }\end{array}$ & $\begin{array}{c}\text { Crimina- } \\
\text { lization }\end{array}$ & $\begin{array}{c}\text { Decrimi- } \\
\text { nalization }\end{array}$ & Total \\
\hline $\begin{array}{l}\text { A 15-year-old knocks down his classmate during } \\
\text { the break and takes away his cell phone worth } \\
55,000 \text { HUF }\end{array}$ & 77 & 22 & 1 & $\mathbf{1 0 0}$ \\
\hline $\begin{array}{l}\text { A 15-year-old takes away his/her classmate's cell } \\
\text { phone worth 55,000 HUF during the break }\end{array}$ & 71 & 27 & 2 & $\mathbf{1 0 0}$ \\
\hline $\begin{array}{l}\text { A 13-year-old knocks down his classmate during } \\
\text { the break and takes away his cell phone worth } \\
55,000 \text { HUF }\end{array}$ & 63 & 36 & 2 & $\mathbf{1 0 0}$ \\
\hline $\begin{array}{l}\text { A 13-year-old takes away his/her classmate's cell } \\
\text { phone worth 55,000 HUF during the break }\end{array}$ & 62 & 36 & 1 & $\mathbf{1 0 0}$ \\
\hline
\end{tabular}

In all four situations, opinions and the supposed regulation coincided in the case of half of the respondents (50\%), while case-independent criminalization is only $16 \%$ and general decriminalization is negligible (1\%). Thus, two-thirds of the respondents have not only schematic knowledge but also schematic opinion.

Hence, we can mainly see opinions behind the reported knowledge: for half of the respondents this may be the most decisive element. In the cases of those who believe that the situation is not punished by law, although they believe it should be punished, in the first three situations we see a lack of knowledge, as those offenses are currently punished. At the same time, those who would criminalize a 13-year-old thief (36\%) should logically be considered 'different,' since they are (apparently) aware of the regulation, which does not make this act punishable. However, almost half of them (15\% of the total sample) have the same pattern for all four situations: they think/know it is not punished by the law but would punish it. Thus, the remaining $21 \%$ of respondents are most likely to answer on the basis of real knowledge that a 13-year-old thief is not punishable, as they did not respond to each questions following a simple pattern.

\subsection{Opinions vs. supposed and actual regulation}

There is a big difference in the assessment of the situations when opinions are contrasted with not only the supposed but the actual regulation. ${ }^{28}$ On the one hand, only $1-2 \%$ of those who know the current regulation well, would change the regulation of the first three situations (that are currently punished). On the other hand, $36 \%$ of the respondents would punish the 13-year-old thieves, while knowing rightly that this is not punishable at the moment.

${ }^{28}$ This is illustrated in three-dimensional tables below, where both the subjective viewpoint (rows) and the objective (in boldface those whose knowledge coincides with the current regulation) are represented. The proportion of each pair of knowledge-opinion can be seen in the cells. 
Table 19. A 15-year-old knocks down his/her classmate during the break and takes away his cell phone worth 55,000 HUF

(percentage;

current regulation in bold)

\begin{tabular}{|l|c|c|}
\hline & $\begin{array}{c}\text { Should be } \\
\text { punishable }\end{array}$ & $\begin{array}{c}\text { Should not be } \\
\text { punishable }\end{array}$ \\
\hline Punishable & $\mathbf{7 2}$ & $\mathbf{1}$ \\
\hline Not punishable & 22 & 5 \\
\hline
\end{tabular}

* Without those who answered "don't know" any question

Table 20. A 15-year-old takes away his/her classmate's cell phone worth 55,000 HUF during the break

(percentage;

current regulation in bold)

\begin{tabular}{|l|c|c|}
\hline & $\begin{array}{c}\text { Should be } \\
\text { punishable }\end{array}$ & $\begin{array}{c}\text { Should not be } \\
\text { punishable }\end{array}$ \\
\hline Punishable & $\mathbf{6 2}$ & $\mathbf{2}$ \\
\hline Not punishable & 27 & 9 \\
\hline
\end{tabular}

* Without those who answered “don't know" any question

Table 21. A 13-year-old knocks down his/her classmate during the break and takes away his cell phone worth 55,000 HUF

(percentage;

current regulation in bold)

\begin{tabular}{|l|c|c|}
\hline & $\begin{array}{c}\text { Should be } \\
\text { punishable }\end{array}$ & $\begin{array}{c}\text { Should not be } \\
\text { punishable }\end{array}$ \\
\hline Punishable & $\mathbf{5 5}$ & $\mathbf{1}$ \\
\hline Not punishable & 36 & 8 \\
\hline
\end{tabular}

* Without those who answered "don't know" any question

Table 22. A 13-year-old takes away his/her classmate's cell phone worth $\mathbf{5 5 , 0 0 0}$ HUF during the break

(percentage;

current regulation in bold)

\begin{tabular}{|l|c|c|}
\hline & $\begin{array}{c}\text { Should be } \\
\text { punishable }\end{array}$ & $\begin{array}{c}\text { Should not be } \\
\text { punishable }\end{array}$ \\
\hline Punishable & 48 & 2 \\
\hline Not punishable & 36 & 14 \\
\hline
\end{tabular}

* Without those who answered "don't know" any question

\subsection{Opinions of socio-demographic groups}

A bivariate logistic regression was run to predict opinion on criminal responsibilities from socio-demographic variables and from legal knowledge concerning the given situation. The 
dependent variable of the regression model was the bivariate, should be punished/shouldn't be punished response for each situation. Among the independent variables, in addition to the socio-demographic variables, we included legal knowledge about the given situation. ${ }^{29}$

The model explained much more $(28-40 \%)$ of the variance in the opinion than it did in the awareness. Again the strongest correlation is between awareness and opinion of the same scenario. There is no statistical proof of the direction of the correlation but is seems plausible that people have opinions on these situations and mention their opinions as knowledge.

The other influential variable in all situations is settlement size: it has a significant $(p=0.05)$ correlation with the opinions on all situations.

Hungarian society has a high willingness to punish crimes against property, especially among those living in the countryside.

Table 23. Opinions on the four situations. Bivariate logistic regression model

\begin{tabular}{|c|c|c|c|c|c|c|c|c|}
\hline & $\begin{array}{c}\text { A } \\
\text { 15-year- } \\
\text { old } \\
\text { knocks } \\
\text { down } \\
\text { and takes } \\
\text { away }\end{array}$ & $\begin{array}{c}\text { Nagelkerke } \\
\mathrm{R}^{2}=0,40\end{array}$ & $\begin{array}{c}\text { A } \\
\text { 15-year- } \\
\text { old takes } \\
\text { away }\end{array}$ & $\begin{array}{c}\text { Nagelkerke } \\
\mathrm{R}^{2}=0,36\end{array}$ & $\begin{array}{c}\text { A } \\
\text { 13-year- } \\
\text { old } \\
\text { knocks } \\
\text { down } \\
\text { and takes } \\
\text { away }\end{array}$ & $\begin{array}{c}\text { Nagelkerke } \\
\mathrm{R}^{2}=0,32\end{array}$ & $\begin{array}{c}\text { A } \\
\text { 13-year- } \\
\text { old takes } \\
\text { away }\end{array}$ & $\begin{array}{c}\text { Nagelkerke } \\
\mathrm{R}^{2}=0,28\end{array}$ \\
\hline & $\mathrm{p}$ & $\exp (B)$ & $\mathrm{p}$ & $\exp (B)$ & $\mathrm{p}$ & $\exp (B)$ & $\mathrm{p}$ & $\exp (B)$ \\
\hline Opinion &, 000 & 20,064 &, 000 & 12,613 & ,000 & 16,440 &, 000 & 12,215 \\
\hline $\begin{array}{l}\text { Settlement } \\
\text { size }\end{array}$ &, 000 & 1,347 &, 000 & 1,265 &, 000 & 1,315 &, 001 & 1,194 \\
\hline Gender & ,081 & 1,971 & ,304 & 1,387 & ,017 & 2,173 & ,005 & 2,163 \\
\hline Church & ,205 & 1,252 & ,002 & 1,641 & ,213 & 1,194 & , 146 & 1,186 \\
\hline Work & , 129 & 849 & ,394 & ,918 & ,074 & 843 & ,024 & ,827 \\
\hline $\begin{array}{l}\text { Number } \\
\text { of people } \\
\text { over } 60\end{array}$ & ,003 & 4,567 & ,564 & 1,285 &, 171 & 1,790 & ,408 & 1,345 \\
\hline $\begin{array}{l}\text { Income } \\
\text { per capita }\end{array}$ & ,235 & 1,000 & ,046 & 1,001 &, 686 & 1,000 & ,752 & 1,000 \\
\hline Age & 049 & ,975 & 907 & 999 &, 050 & ,978 &, 545 & 994 \\
\hline $\begin{array}{l}\text { Involved } \\
\text { in crime }\end{array}$ & ,832 & ,895 & , 170 & 1,695 & ,309 & 1,462 & ,041 & 1,860 \\
\hline
\end{tabular}

29 The following independent variables were included in the analysis: Gender (1: male; 2: female); Financial situation (1: better; 2: about the same; 3: worse than other Hungarian families); Size of settlement (less than 1: 1000 inhabitants; 8: more than 100,000 inhabitants, 9: Budapest); Do you go to church? (1: several times a week; 6 : does not go to church or religious gatherings at all); Work (1: full-time; 8: inactive earner); Family size; Number of people over 60; Number of children under 18; Per capita income; Age; Education; Do you watch TV news? (0: no; 1: watch RTL or TV2 News at least once a week); Have you been involved in a crime? (0: no, 1: yes); Do you read a daily newspaper? (1: no; 2: yes); What do you think about the given situation? (1: should be punish; should not be punished). 


\begin{tabular}{|l|c|c|c|c|c|c|c|c|}
\hline & $\begin{array}{c}\text { A } \\
\text { 15-year- } \\
\text { old } \\
\text { knocks } \\
\text { down } \\
\text { and takes } \\
\text { away }\end{array}$ & $\begin{array}{c}\text { Nagelkerke } \\
\mathrm{R}^{2}=0,40\end{array}$ & $\begin{array}{c}\text { A } \\
\text { 15-year- } \\
\text { old takes } \\
\text { away }\end{array}$ & $\begin{array}{c}\text { Nagelkerke } \\
\mathrm{R}^{2}=0,36\end{array}$ & $\begin{array}{c}\text { A } \\
\text { 13-year- } \\
\text { old } \\
\text { knocks } \\
\text { down } \\
\text { and takes } \\
\text { away }\end{array}$ & $\begin{array}{c}\text { Nagelkerke } \\
\mathrm{R}^{2}=0,32\end{array}$ & $\begin{array}{c}\text { A } \\
\text { 13-year- } \\
\text { old takes } \\
\text { away }\end{array}$ & $\begin{array}{c}\text { Nagelkerke } \\
\mathrm{R}^{2}=0,28\end{array}$ \\
\cline { 2 - 10 } & $\mathrm{p}$ & $\mathrm{exp}(\mathrm{B})$ & $\mathrm{p}$ & $\mathrm{exp}(\mathrm{B})$ & $\mathrm{p}$ & $\mathrm{exp}(\mathrm{B})$ & $\mathrm{p}$ & $\mathrm{exp}(\mathrm{B})$ \\
\hline Newspaper &, 270 &, 646 &, 014 & 2,198 &, 064 & 1,809 &, 015 & 1,946 \\
\hline Education &, 900 &, 969 &, 809 &, 950 &, 081 &, 674 &, 167 &, 770 \\
\hline Family size &, 494 & 1,156 &, 917 & 1,018 &, 195 &, 784 &, 891 & 1,019 \\
\hline $\begin{array}{l}\text { Number } \\
\text { of children } \\
\text { under 18 }\end{array}$ &, 939 &, 976 &, 151 & 1,417 &, 222 & 1,423 &, 892 & 1,030 \\
\hline $\begin{array}{l}\text { Financial } \\
\text { situation }\end{array}$ &, 350 & 1,411 &, 591 & 1,180 &, 199 & 1,502 &, 421 & 1,230 \\
\hline $\begin{array}{l}\text { Watching } \\
\text { the news }\end{array}$ &, 267 &, 643 &, 192 &, 639 &, 312 & 1,447 &, 867 & 1,053 \\
\hline
\end{tabular}

$\mathrm{p}=0,05$; significant variables with grey background

\section{CONCLUSION}

\subsection{Results}

Age limits of criminal responsibility for crimes against property are relatively well-known among the general population. Most of the respondents are aware that 15-year-old robbers $(73 \%)$ and thieves $(63 \%)$ are punishable. Only the case of a 13-year-old thief seems to be the odd one out: a relatively large group of people (44\%) are not aware that a 13-year-old thief does not commit a crime. However, the second largest group (22\%) in this respect is made up of precisely those who could judge only this question correctly and therefore answered all other situations wrongly, believing that the acts are not punished. In contrast to these groups, however, a small percentage of the population (3\%) is aware of the full range of legal rules on the age-limit of criminal responsibility for offences against property.

The willingness of Hungarian society to punish is high with regard to age-limits of criminal responsibility for crimes against property. Opinions (similarly to knowledge) also tend to follow a pattern: $79 \%$ of respondents say that every case should be punished. Thus, two-thirds of the respondents do not only think that the same regulation apply in all the cases but they do not differentiate in their opinion either. In this category, the most serious case, a 15-year-old robber, would be punished by $92 \%$ of the respondents but even the slightest act (theft by a 13 -year-old) would be punished by $83 \%$. Those who differentiated are more lenient towards 13-year-olds and thieves. However, only $3 \%$ of the population would regulate according to our criminal law on the age-limit of criminal responsibility in each and every detail examined, namely in leaving 13-year-old thieves unpunished.

Knowledge may also be significantly influenced by opinions, which may be the most decisive element. In all four situations, opinions and the supposed regulation coincided in the case of half of the respondents $(50 \%)$, while case-independent criminalization is only $16 \%$ and general decriminalization is negligible (1\%). Two thirds of the respondents have not only schematic knowledge but also schematic opinion. 
Differences in opinion and knowledge tend to lead to criminalization (22-36\% depending on situation). There is a higher percentage of those who want to criminalize when it comes to 13-year-old perpetrators, as they know (wrongly for robbers, rightly for thieves) that they are currently not being punished and they do not agree with the (supposed) law.

When comparing opinions with supposed and actual regulation, we find a big difference in the perception of each situation. Only 1-2\% of those, who know the current regulation well, would change the first three situations, which are currently punished. The only exception is the 13-year-old thief, who would be punished by $36 \%$ of all respondents, knowing that this is not punishable at the moment.

\subsection{Hypotheses}

The hypotheses on legal consciousness have only been partially substantiated with regard to the age-limit of criminal responsibility for offences against property.

It was verified that the average person has a fragmented knowledge about this field of criminal law. The schematic (undifferentiated) nature of the usual answers does not mirror the distinctions of the criminal code. Therefore, it was supposed that the source of the knowledge was rarely the positive law.

It was not substantiated that knowledge of law is affected by socio-economic factors, by media consumption or by encountering criminality. The answers may have been influenced by attitudes towards the topic more vigorously.

The hypothesis regarding the novelties was neither substantiated nor should be rejected. The novelty of the regulation, 13-year-old robbers are punishable, was not the least-known situation. Nevertheless, if this case is only compared with the two other situations where 'the act is punishable' is the right answer, this is indeed the least known regulation.

\section{LITERATURE}

Engel, D., 'How Does Law Matter in the Constitution of Legal Consciousness?' in B Garth and A Sarat (eds), How Does Law Matter? (Northwestern University Press 1998) 109-44.

Fekete, B. and Gajduschek, Gy., 'Changes in Knowledge About Law in Hungary in the Past Half Century' (2015) 57 Sociologija 620-36.

Fekete, B. and H. Szilágyi, I., 'Knowledge and Opinion about Law (KOL) Research in Socialist Hungary' (2017) 58 Hung. J. Legal Stud. 326-58. <https://doi.org/10.1556/2052.2017.58.3.6>.

Hertogh, M., Nobody's Law: Legal Consciousness and Legal Alienation in Everyday Life (Palgrave Macmillan 2018).

Hertogh, M., 'Loyalists, Cynics and Outsiders: Who are the Critics of the Justice System in the UK and the Netherlands?' (2010) 7 International Journal of Law in Context 31-46. <https://doi. org $/ 10.1017 / \mathrm{S} 174455231000039 \mathrm{X}>$.

Hertogh, M., 'A European Conception of Legal Consciousness: Rediscovering Eugen Ehrlich' (2004) 4 Journal of Law and Society 457-81. <https://doi.org/10.1111/j.1467-6478.2004.00299>.

Kelemen, L., Miként vélekedünk a jogról? (What Do We Think about Law?) (Line Design 2010).

Király, R., 'A 14. születésnap mint korhatár' ('14th birthday as a threshold of responsibility') (2005) 1 Család és Jog 17-25.

Kulcsár, K., A jogismeret vizsgálata (Researching Knowledge of Law) (MTA ÁJTI 1967).

Sajó, A., Jogtudat, jogismeret (Legal Consciousness and Knowledge of the Law) (MTA SZI 1983).

Sajó, A., Látszat és valóság a jogban (Appearance and Reality in Law) (KJK 1986).

Sajó, A., Székelyi, M. and Major, P., Vizsgálat a fizikai dolgozók jogtudatáról (Survey on the Legal Consciousness of Physical Workers) (MTA ÁJTI 1977).

Tóth, M., 'Az új Btk. bölcsőjénél' ('At the Cradle of the New Hungarian Criminal Code') (2013) 9 Magyar Jog 525-34. 
Vaskuti, A., 'Életkor és belátási képesség a magyar büntetőjogban - jogalkotási és jogalkalmazási kérdések' ('Age and discernment in Hungarian criminal law: Issues in legislation and the application of law') Aszódi Javitóintézet Módszertani Levél (October, 2009) <http://www.aszodafi.hu/pdf/vaskuti_eloadas.pdf $>$ Accessed 6 December 2018.

\section{OPEN ACCESS}

This is an open-access article distributed under the terms of the Creative Commons Attribution 4.0 International License (https://creativecommons.org/licenses/by/4.0), which permits unrestricted use, distribution, and reproduction in any medium, provided the original author and source are credited, a link to the CC License is provided, and changes - if any - are indicated. (SID_1). 